\title{
Az orvos-beteg kommunikáció jelentősége a szomatizáló páciensek ellátásában
}

\author{
Stauder Adrienne dr. ${ }^{1}$ - Eörsi Dániel dr. ${ }^{2}$ - Pilling János dr. ${ }^{1}$ \\ ${ }^{1}$ Semmelweis Egyetem, Általános Orvostudományi Kar, Magatartástudományi Intézet, Budapest \\ ${ }^{2}$ Háziorvosi Szolgálat, Budapest, Ferenc tér
}

\begin{abstract}
Szomatizáció alatt a szervi elváltozásokkal megnyugtatóan nem magyarázható testi panaszok összességét értjük. Szakirodalmi adatok alapján az orvos-beteg találkozások 15-25\%-a ilyen jellegú probléma miatt jön létre. Mivel a hazai orvosképzésben a testi panaszok esetleges lelki hátterének értékelése nem kap megfelelő hangsúlyt, az orvosok attitűdjét gyakran tehetetlenségérzés, előítéletek jellemzik, ehhez pedig nem teljesen megindokolható diagnosztikus, illetve terápiás beavatkozások elrendelése társulhat. Mindeközben a páciens is tehetetlen, szorongása fokozódhat, panaszainak intenzitása nőhet. Mivel a szomatizáció egyik kiváltó oka a stressz, ezért kezelésének kulcsa a stresszel való megküzdés javítása. Ez a legtöbb krónikus betegség szakmai terápiás irányelveiben megjelenik. A rendelkezésre álló, hatékony beavatkozások repertoárja a mindennapi betegellátásba illeszkedő rövid tanácsadástól a gyógyszeres kezelésen át a pszichoterápiákig terjed. Vizsgálati eredmények alapján a leghatékonyabbak a kognitív és viselkedésterápiás beavatkozások. Ugyanakkor a betegek egy részénél a családorvosi vagy szakorvosi ellátás keretében történő rövid (10-30 perc), strukturált, úgynevezett reattribúciós tanácsadással is szignifikáns testi tünet- és szorongáscsökkenést lehet elérni. Orv. Hetil., 2016, 157(17), 664-668.
\end{abstract}

Kulcsszavak: stresszkezelés, szomatizáció, reattribúció, orvos-beteg kommunikáció

\section{The importance of the doctor-patient communication in the care of somatizing patients}

The term "somatization" refers to the manifestation of multiple somatic complaints not explained by organic changes. According to the literature, 15-25 percent of all medical visits are related to somatization. As medical training does not put enough emphasis on the evaluation of the possible psychological background of certain somatic symptoms, physicians may feel powerless and make unjustified diagnostic and therapeutic efforts. The patients may also feel helpless and frustrated, their anxiety and the intensity of their complaints may increase. As stress is an important factor in the somatization process, stress reduction and improvement of coping are key elements of the treatment guidelines for chronic diseases. Evidence based interventions range from short counselling and medication to cognitive and behavioral psychotherapy. Reattribution, a short (10-30 minutes) structured intervention that can be implemented in primary or secondary care, in certain cases can result in significant decrease in somatic symptoms and anxiety.

Keywords: stress management, somatization, reattribution, doctor-patient communication

Stauder, A., Eörsi, D., Pilling, J. [The importance of the doctor-patient communication in the care of somatizing patients]. Orv. Hetil., 2016, 157(17), 664-668.

(Beérkezett: 2016. február 26.; elfogadva: 2016. március 17.)

A szomatizáció tárgykörébe azok a krónikus testi panaszok (fájdalmak, diszkomfortérzések, vegetatív funkciók zavarai) tartoznak, amelyek mögött nem áll a panaszok súlyosságát indokoló organikus elváltozás. Bár a panaszok jellege, lokalizációja, időbeli lefolyása rendkívül szerteágazó, a hozzájuk vezető kognitív és emocionális mintázatok között van hasonlóság.

A szervi elváltozással nem magyarázható tünetek nozológiai kategorizálása meglehetősen bonyolult és sokat változott az elmúlt évtizedekben. Egyrészt a vezető 
tünetnek megfelelő szervrendszer betegségei között tartjuk óket nyilván, például irritábilis bél szindróma, halmozott fejfájás szindróma stb. Másrészt, felismerve, hogy a jelenség lélektani folyamatokhoz köthető, a BNO-10 a mentális betegségek közé sorolva szomatoform rendellenességeket is megnevez, hét alkategóriát elkülönítve, ezek közül az egyik a szomatizációs zavar. Az alkategóriák közötti differenciáldiagnózis a gyakorlat számára kevés haszonnal kecsegtet, ezért a 2013ban elfogadott DSM-5 egyetlen kategóriát, „szomatikus tünet zavart" jelöl meg, amely egyesíti a korábban elkülöníthetőnek tekintett klinikai entitásokat. A DSM5 definíciója szerint a testi tünet zavar akkor mondható ki, ha a legalább hat hónapja fennálló egy vagy több testi tünet jelentős szenvedést, érzelmi, kognitív vagy viselkedésbeli zavart okoz. Jelen tanulmányunkban a magyar szaknyelvben leginkább elterjedt szomatizáció kifejezést a testi tünet zavar szinonimájaként használjuk.

A szomatizáció előfordulási gyakorisága nemzetközi vizsgálatok szerint 4,4-19\% lakossági vizsgálatokban; az alapellátásban pedig 7,3-35\% (medián: 16,6\%) [1, 2]. Hazai vizsgálatok hasonló képet mutatnak: a Hungarostudy 2006 reprezentatív lakossági vizsgálatban a PHQ15 szubjektív testi tüneti skálán szomatizációra utaló magas pontszámot a lakosság 14,1\%-a ért el [3]. Csabai vizsgálatában [4] 170 megkérdezett magyarországi orvos saját praxisában átlagosan $30 \%$-ra becsülte a szomatizáló betegek arányát; ez az arány a háziorvosok (a betegforgalom 38,2\%-a), illetve a belgyógyászok szerint $(41,6 \%)$ volt a legmagasabb. A vizsgálatok szerint a szomatizáló betegek körülbelül felénél egyéb pszichiátriai zavar, elsősorban hangulati és/vagy szorongásos zavar is diagnosztizálható [1].

\section{A szomatizáció etiológiája}

A tünetképződés folyamatában hajlamosító tényezőket, kiváltó tényezőket és fenntartó tényezőket lehet azonosítani [2].

\section{Hajlamositó tényezők}

Bár egyes betegcsoportoknál bizonyos genetikai faktorok jelentősége is kimutatható [5], a szomatizációra való hajlam alapvetően tanulási folyamat következtében alakul ki. Elsősorban a szülői szorongás, depresszió, családban előfordult testi betegség vagy szomatizáció, másodsorban egyéb környezeti minták mentén a testi tünetek jelentősége felértékelődik. A páciens beállítódására jellemző lehet, hogy személyes fontosságát az esetleges testi tüneteken, betegségeken keresztül tudja leginkább megélni. Az érzelmek tudatosításának, kifejezésének nehezítettsége (alexithymia) szintén hajlamosító tényező.

\section{Kiváltó tényezôk}

A stressz koncepciója jól használható értelmezési keretet nyújt annak megértéséhez, hogy egyes tünetek és betegségek kialakulását milyen módon befolyásolhatják a pszichoszociális hatások, hogyan lehetnek védő vagy kockázati tényezôk az interperszonális kapcsolatok. A stresszalapú megközelítés lehetővé teszi a szomatizáló páciensekkel kapcsolatos hatékonyabb kommunikációs stratégia kialakítását, illetve megteremti a lehető leghatékonyabb terápiás intervenciók alapját.

Selye János 1936-ban megjelent cikkében írta le először a szervezet nem specifikus reakcióját, amely „stressz” néven került be a köztudatba. Magát a stresszt kiváltó tényezőt stresszornak nevezte el [6]. A stresszor hatására bekövetkező aspecifikus élettani változások és tünetképződés folyamatát „általános adaptációs szindrómának” nevezte, azon belül három egymást követő szakaszt különített el: 1. az alarm vagy vészreakció szakaszát, 2 . az ellenállás szakaszát és 3. a kimerülés szakaszát. A streszszor hatására a hypothalamus-hypophysis-mellékvese (HHM) tengely és a szimpatikus idegrendszer aktiválódik, s bonyolult neuroendokrin szabályozórendszereken keresztül az egyes szervek és szervrendszerek, illetve az anyagcsere és a sejtmúködés szintjén is élettani változásokhoz vezet [7]. Alaphelyzetben a stressz elmúltával a szervezet múk ödési egyensúlya helyreáll. Tartósan fennálló stressz esetén azonban különböző funkcionális, majd organikus tünetek jelennek meg [8-10]. A pszichoszociális stresszorok által kiváltott élettani reakciók intenzitását befolyásolják az egyén korábbi tapasztalatai, megküzdési stratégiái és a stresszhelyzethez kapcsolódó érzelmi állapota is [11].

Az esetek egy részében kiváltó tényezőként intenzív pszichoszociális stresszhatások, traumák, bántalmazás, súlyos testi betegség, közeli hozzátartozó betegsége tárhatók fel. Ugyanakkor számos, nem egyértelmúen negatív életesemény is tekinthető stresszornak, ilyen például a házasságkötés, gyermek születése, munkahely-változtatás, anyagi helyzet megváltozása [12]. Az esetek más részében egyértelmü akut stresszor nem igazolható, azonban a kisebb intenzitású, de ismétlődő vagy állandósuló, elkerülhetetlen mindennapi stresszhelyzetek öszszességükben szintén vezethetnek testi tünetek kialakulásához. A tünetek kezdete gyakran egy önmagában banális szervi megbetegedéshez, például vírusfertőzéshez köthető.

\section{Fenntartó tényezők}

Bár maguk a tünetek szerteágazóak, a szomatizáló páciensek mentális múködése viszonylag tipikusnak mondható (1. ábra). Jellemző a fokozott önmonitorozás, a testi tünetek figyelése és keresése, illetve az ezek miatt érzett aggodalom. Az introspekció során a páciens előbb-utóbb felfedez olyan testi élményeket, amelyek máskülönben nem tudatosodnának, ez pedig megerősíti betegségtuda- 
tát, szorongása fokozódik, ami a szimpatikus aktiváción keresztül további tünetek képződéséhez vezethet. Szomatoszenzoros amplifikációnak hívjuk azt a jelenséget, amikor egyes bizonytalan testi érzetek felerösödnek, kifejezetten kellemetlennek, fájdalmasnak érződnek; hátterében az információfeldolgozás zavarát igazolták [13, 14].

A betegség-szorongás miatt a páciens aktivitása csökken, az elkerülő magatartás azonban tovább rontja a tüneteket. Például, ha a krónikus fájdalom miatt kevesebbet mozog a beteg, akkor az izmok fokozott feszülése és az ízületi mozgások beszúküulése tovább fokozza a fájdalmat. A páciens egyre több időt tölthet magával a betegséggel: információkat gyüjt, orvosokhoz jár, könyveket szerez be, az internetet bújja, saját magát figyeli, alternatív gyógymódokat keres.

A szomatizáló páciens betegségelőnyöket élhet át, amelyek maguk is fenntartó tényezőkké válhatnak. Betegségelőnynek olyan, részben tudattalan folyamatokat nevezünk, amelyek a páciens számára bár egyértelmú örömforrást nem jelentenek, mégis bizonyos téren megkönnyítik a különböző élethelyzetekhez történő adaptációt (fokozott figyelem, betegállomány, mentesülés bizonyos feladatok alól, személyes fontosság érzése a betegségen keresztül stb.).

A fenntartó tényezők közül kiemelt jelentősége van az iatrogeniának. Mivel a szervi eltérések hiánya a laikus környezetból és az orvosokból is lekezelést, elöítéleteket válthat ki, a szomatizáció tényét gyakran nem mondják ki, a kezelőorvosok mindenáron objektív organikus, lehetőleg megszüntethető elváltozás kimutatására törekednek. Emiatt diagnosztikus vizsgálatok és terápiás kísérletek sorát rendelik el, mindez azonban ismétlődő frusztrációval, csalódottsággal jár mindkét fél számára. $\mathrm{Az}$ újabb orvosi vizsgálatok kimutathatnak orvosi szempontból jelentéktelen, illetve ártalmatlan, de a beteget élénken foglalkoztató eltéréseket, amelyek tovább növelik a páciens szorongását. Minél több vizsgálaton vesz részt a páciens, annál inkább megerősödik benne az az érzés, hogy lennie kell valami betegségnek, amit az orvosok nem találnak. Az orvos-beteg kapcsolat idóvel demoralizálódik, a páciens szorongása pedig tovább fokozódik [15].

\section{Kezelés}

A szomatizáló páciensekkel folytatott kommunikáció során fontos az elöítélet-mentesség, tartsuk szem előtt azt, hogy a szomatizáló beteg a panaszait valóban érzi, s ezek számára szenvedést jelentenek. Kiemelten fontos a pszichoszociális anamnézis felvétele, különös tekintettel a tünetek kialakulásának idején bekövetkezett stresszhatásokra, változásokra. Hasznos lehet tüneti napló vezetését kérni, amelyben a páciens rögzítheti tüneteit, azok intenzitását, a tünetekkel eltöltött időt, stresszhelyzeteit, valamint azt is, hogy mit tett a tünetek leküzdése érdekében. A tüneti napló segít feltérképezni, milyen körülmények között erősödnek fel a tünetek (tipikusan nyugalomban, amikor fokozott önmegfigyelésre van lehetőség), illetve hosszú távon objektívebben lehet megítélni a tünet változásait. A napló segíthet abban is, hogy a tünetek (ismételt) felsorolása helyett a jelenségek megnyugtató magyarázata és a terápiás lehetőségek megbeszélése kerüljenek előtérbe.

Klinikai kutatások igazolják, hogy az orvos megfelelő kommunikációja csökkentheti a szubjektív panaszok számát, az egészséggel kapcsolatos szorongást, az egészségügyi szolgáltatások igénybevételét, illetve javíthatja a betegek elégedettségét és mindennapi életét [16].

\section{Pszichoedukáció}

A szomatizáció kezelésének alapja a pszichoedukáció, amely nem igényel külön képzettséget, bármilyen orvos-

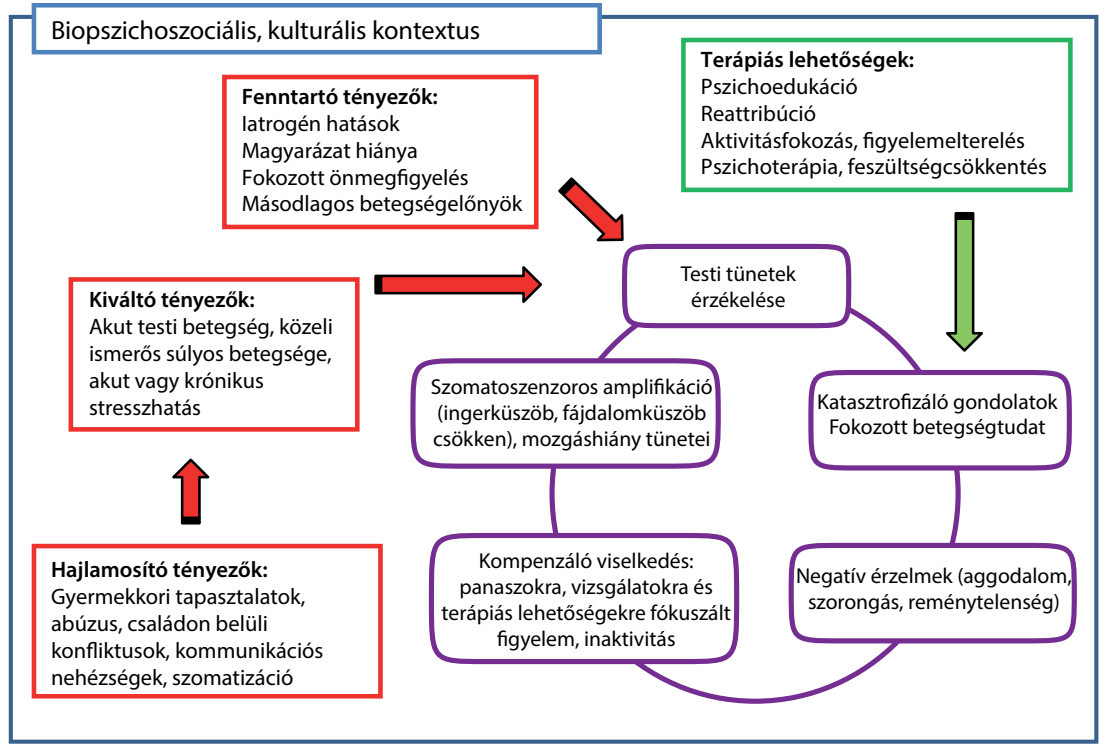

1. ábra

| A szomatizáció önrontó köre 
beteg találkozás keretein belül alkalmazható. Ennek lényege, hogy a szomatizáció mint diagnózis legyen nyíltan megfogalmazva, és az orvos koherens magyarázatot szolgáltasson a beteg által tapasztalt testi és lelki tünetekre. Megismertetjük a pácienssel a szomatizáció kialakulásához és fennmaradásához vezető legfontosabb tényezőket, bemutatjuk az önmegfigyelés és a tünetek miatti szorongás úgynevezett önrontó körét (1. ábra).

A testi és a lelki folyamatok összekapcsolásában támaszkodhatunk az anamnézisre és a tüneti naplóra, illusztrációként hétköznapi példákat használhatunk (például, ha citromra gondolok, összefut a nyál a számban; ha csendben figyeljük, az óra ketyegése sokkal hangosabbnak tünik). Mivel a szomatizáció fontos eleme a tünetek súlyosságának túlértékelése, kiemelt hangsúlyt kell, hogy kapjon a katasztrofizáló gondolatok feltárása, a testi érzetek normalizálása, illetve annak tudatosítása, hogy az elkerülő magatartás nem megoldás, hanem további problémák forrása. Fontos felhívni a páciens figyelmét az inaktivitás veszélyeire és a relaxáció kiemelt jelentőségére.

\section{Reattribúció}

A reattribúció egy speciális tréning segítségével elsajátítható, kognitív és viselkedésterápián alapuló technika, amelynek segítségével a kezelőorvos hatékonyabb támogatást tud nyújtani szomatizáló pácienseinek [2, 17]. A páciens és az orvos aktív részvételét igénylő folyamat elemei a következők:

- Elfogadás és megnyugtatás. Célja a páciens szubjektív betegségképének megismerése. A páciens egyes szavakat („lelki”, „idegi”, „pszichológia”) stigmatizálónak élhet meg, ezért az ő szóhasználatához alkalmazkodjunk. Célszerű ismertetni a szomatizáció gyakoriságát.

- Átkeretezés. Célja, hogy a pszichoszociális anamnézisfelvételt követően megismertessük páciensünkkel a stresszorok kóroki szerepét.

- Összekapcsolás. Célja, hogy - a betegedukációnál már említett - hétköznapi példák segítségével a páciens felismerje és elfogadja a testi folyamatok, valamint a kognitív és emocionális tényezők összefüggéseit.

- Együttmüködés kialakitása. Célja a páciens szenvedésnyomásának és motivációjának megismerése, saját erōforrásainak feltárása, és ezek alapján terápiás terv kialakítása, amelynek célja a panaszokat fenntartó önrontó kör megszakítása.

A reattribúció ismétlődő, rendszeres találkozásokon alapul, és reális célkitűzés köré szerveződik, amely nem feltétlenül a tünetmentességet jelenti.

A reattribúciós tréningek hatásait utánkövetéses vizsgálatokban mérték. Az eredmények szerint már egy hónapon belül érezhető volt a tréning hatása, három hónapon belül pedig jelentősen javult a tréningen részt vevő orvosok betegeinek életminősége. Csökkent a fizikai tünetek száma, mérséklődött a szorongás és a depresszió mértéke, javult a betegek funkcionális állapota [18], il- letve az orvoshoz fordulás gyakorisága, és az egészségügyi ellátás költségei is csökkentek. A testi tünetek öszszességükben kisebb mértékben javultak, mint a tünetek miatti distressz és orvoshoz fordulás [19]. A reattribúció technikáját alkalmazó orvosok saját magukat kompetensebbnek tartják, kommunikációjuk betegcentrikusabbá vált, pácienseik nagyobb valószínüséggel fogadnak el pszichoterápiát [14].

\section{Pszichoterápia}

A pszichoterápia külön szakképzéshez kötött szakmai tevékenység, amely a szomatizáló páciensek csak egy kisebb csoportja számára jelent megoldást, hiszen a funkcionális tünetekkel küzdő betegeknek csak egy része motivált arra, hogy pszichológushoz vagy pszichiáterhez forduljon. A lélektani irányú beavatkozás sikeressége nagymértékben függ a páciens betegségképétől, tehát, hogy ô maga mennyire feltételez pszichoszociális tényezőket a háttérben. A pszichoterápia célja, hogy a páciens képes legyen változtatni a szomatizációhoz vezető és azt fenntartó mentális és emocionális mintázatain.

A legtöbb pszichoterápiás módszernek van saját értelmezési koncepciója és kezelési stratégiája a szomatizáció vonatkozásában, közülük a kognitív és viselkedésterápia hatékonyságára van $A$ szintü evidencia $[20,21]$. A kognitív és viselkedésterápia célja a gondolkodási hibák felismerése és korrigálása, gyakori elemei a kognitív átkeretezés, valamint az asszertív viselkedés és az indulatkezelés technikájának elsajátítása [22]. Tágabb értelemben a kognitív és viselkedésterápiás technikák közé soroljuk a relaxációs módszereket, illetve az utóbbi években egyre elterjedtebben használt és kiemelkedően hatékonynak talált „elfogadás és elköteleződés” terápiát. Ez utóbbi a tünetmentesség elérése helyett a tünetek elfogadására és az aktivitás fokozatos növelésére helyezi a hangsúlyt, ezáltal szakítva meg az önrontó köröket [23]. A kapcsolatok javítása, az érzelmek tudatosítása és kifejezése, illetve a figyelem átirányítása a testi tünetekről az interperszonális kapcsolatokra szintén hatékony eleme a pszichoterápiáknak [24]. Mindez egyéni és csoportterápiás keretek között is elérhető. A csoportos tanulás a költséghatékonyságon túl számos előnnyel jár. A résztvevők közötti tapasztalatcsere elősegítheti a kognitív torzítások felismerését és korrigálását. A csoport tágabb teret nyújt az élmények megosztására, visszajelzésekre, a kommunikációs készségek gyakorlására a társas kapcsolatok javítása érdekében.

\section{Gyógyszeres kezelés}

Amennyiben a páciensnél egyértelmú szorongásos vagy affektív zavar diagnosztizálható, az antidepresszáns kezelés hatékony lehet a szomatikus tünetek csökkentésében is $[21,25]$. 


\section{Következtetések}

Az orvos-beteg találkozások során gyakran szomatizációra utalnak a panaszok. A diagnózist követően hatékony kommunikációs technikák alkalmazásával lehet a betegeket megnyugtatni és a megfelelő terápiát biztosítani. Ezen technikák elsajátítása és alkalmazása az orvosok kompetenciaérzését is növeli. Ugyanakkor egyes szerzők felhívják a figyelmet arra is, hogy a kommunikációs skillstréningek fejlesztik ugyan a betegcentrikus attitűdöket és készségeket, a tanultak alkalmazása azonban a mindennapi gyakorlatban nem mindig valósul meg teljes mértékben. Bár a résztvevők általában megértik és fontosnak tartják a képzés céljait, rögzült attitűdjeik miatt mindennapi gyakorlatuk gyakran csak kevésbé változik meg. A kommunikációs képzések során ezért fontos az attitüdök befolyásolására is törekedni [26]. Konkrét továbbképzés formájában reattribúciós tréning hazánkban jelenleg nincs, de a szomatizáló betegekkel való kommunikáció ma már az orvosképzés tananyagának részét képezi [27].

Anyagi támogatás: A közlemény megírása, illetve a kapcsolódó kutatómunka anyagi támogatásban nem részesült.

Szerzői munkamegosztás: S. A.: A tanulmány struktúrájának kidolgozása, a kézirat megszövegezése. E. D., P. J.: A kézirat megszövegezése. A kézirat végleges változatát mindhárom szerző elolvasta és jóváhagyta.

Érdekeltségek: A szerzőknek nincsenek érdekeltségeik.

\section{Irodalom}

[1] Creed, F., Barsky, A.: A systematic review of the epidemiology of somatisation disorder and hypochondriasis. J. Psychosom. Res., 2004, 56(4), 391-408

[2] Mayou, R., Farmer, A.: Functional somatic symptoms and syndromes. Br. Med. J., 2002, 325(7358), 265-268.

[3] Cserbáti, Z., Stauder, A.: Subjective somatic symptoms and somatization. In: Kopp, M. (ed.): Hungarian state of mind, 2008. [Szubjektív testi tünetek és szomatizáció. In: Kopp, M. (szerk.): Magyar lelkiállapot, 2008.] Semmelweis Kiadó, Budapest, 2008. [Hungarian]

[4] Csabai, M.: Migration of the symptoms. From hysteria to chronic fatigue. [Tünetvándorlás. A hisztériától a krónikus fáradtságig.] Jószöveg Múhely Kiadó, Budapest, 2007. [Hungarian]

[5] Henningsen, P., Creed, F.: The genetic, physiological and psychological mechanisms underlying disabling medically unexplained symptoms and somatisation. J. Psychosom. Res., 2010, 68(5), 395-397.

[6] Selye, J.: Stress without distress. [Stressz distressz nélkül.] Akadémiai Kiadó, Budapest, 1976. [Hungarian]

[7] Heim, C., Ehlert, U., Hellhammer, D. H.: The potential role of hypocortisolism in the pathophysiology of stress-related bodily disorders. Psychoneuroendocrinology, 2000, 25(1), 1-35.

[8] Eriksen, H. R., Ursin, H.: Subjective health complaints, sensitization, and sustained cognitive activation (stress). J. Psychosom. Res., 2004, 56(4), 445-448.

[9] Stauder, A.: Stress and stress management. In: Kállai, J. Varga, J., Oláh, A. (eds.): Health psychology in practice. [Stressz és streszszkezelés. In: Kállai, J., Varga, J., Oláh, A. (szerk.): Egészségpszi- chológia a gyakorlatban.] Medicina Könyvkiadó, Budapest, 2007, 153-176. [Hungarian]

[10] Boone, J. L., Christensen, J. F.: Stress and disease. In: Feldman, M. D., Christensen, J. F. (eds.): Behavioural medicine in primary care. A practical guide. Appleton and Lange, Stamford, 1998.

[11] Ursin, H., Eriksen, H. R.: The cognitive activation theory of stress. Psychoneuroendocrinology, 2004, 29(5), 567-592.

[12] Holmes, T. H., Rabe, R. H.: The social readjustment rating scale. J. Psychosom. Res., 1967, 11(2), 213-218.

[13] Nakao, M., Barsky, A. J.: Clinical application of somatosensory amplification in psychosomatic medicine. Biopsychosoc. Med., 2007, 1, 17.

[14] Weiland, A., Blankenstein, A. H., Van Saase, J. L., et al.: Training medical specialists to communicate better with patients with medically unexplained physical symptoms (MUPS). A randomized, controlled trial. PloS ONE, 2015, 10(9), e0138342.

[15] Kulcsár, Zs., Kapusi, Gy.: The problem of somatization in family medicine I. [A szomatizáció problémája a családorvosi gyakorlatban I.] Családorvosi Fórum, 2004, 5(6), 54-58. [Hungarian]

[16] Weiland, A., van de Kraats, R. E., Blankenstein, A. H., et al.: Encounters between medical specialists and patients with medically unexplained physical symptoms; influences of communication on patient outcomes and use of health care: a literature overview. Perspect. Med. Educ., 2012, 1(4), 192-206.

[17] Goldberg, D., Gask, L., O'Dowd, T.: The treatment of somatization: teaching techniques of reattribution. J. Psychosom. Res., 1989, 33(6), 689-695.

[18] Larisch, A., Schweickhardt, A., Wirsching, M., et al.: Psychosocial interventions for somatizing patients by the general practitioner: a randomized controlled trial. J. Psychosom. Res., 2004, 57(6), 507-514.

[19] Gask, L., Dowrick, C., Salmon, P., et al.: Reattribution reconsidered: narrative review and reflections on an educational intervention for medically unexplained symptoms in primary care settings. J. Psychosom. Res., 2011, 71(5), 325-334.

[20] Sumathipala, A.: What is the evidence for the efficacy of treat ments for somatoform disorders? A critical review of previous intervention studies. Psychosom. Med., 2007, 69(9), 889-900.

[21] Sharma, M. P., Manjula, M.: Behavioural and psychological management of somatic symptom disorders: an overview. Int. Rev. Psychiatry, 2013, 25(1), 116-124.

[22] Perczel Forintos, D.: Cognitive-behavioral therapy of health anxiety and somatization. In: Mórotz, K., Perczel Forintos, D. (eds.): Cognitive-behavioral therapy. [Az egészségszorongás és a szomatizáció kognitív viselkedésterápiája. In: Mórotz, K., Perczel Forintos, D. (szerk.): Kognitív viselkedésterápia.] Medicina Könyvkiadó, Budapest, 2006, 369-416. [Hungarian]

[23] Ruiz, F. J.: A review of acceptance and commitment therapy (ACT) empirical evidence: correlational, experimental psychopathology, component and outcome studies. Int. J. Psychology Psychol. Ther., 2010, 10(1), 125-162.

[24] Stuart, S., Noyes, R. Jr., Starcevic, V., et al.: An integrative approach to somatoform disorders combining interpersonal and cognitive-behavioral theory and techniques. J. Contemp. Psychother., 2008, 38(1), 45-53.

[25] Somashekar, B., Jainer, A., Wuntakal, B.: Psychopharmacotherapy of somatic symptoms disorders. Int. Rev. Psychiatry, 2013, 25(1), 107-115.

[26] Bombeke, K., Symons, L., Vermeire, E., et al.: Patient-centredness from education to practice: the 'lived' impact of communication skills training. Med. Teach., 2012, 34(5), e338-e348.

[27] Pilling, J., Cserbáti, Z.: Communication with somatizing patients. In: Pilling, J. (ed.): Medical communication. [Kommunikáció szomatizáló páciensekkel. In: Pilling, J. (szerk.): Orvosi kommunikáció.] Medicina Könyvkiadó, Budapest, 2008, 210-226. [Hungarian]

(Stauder Adrienne dr., Budapest, Nagyvárad tér 4., 1089 e-mail: stauder.adrienne@med.semmelweis-univ.hu) 